\title{
1 Use of a participatory approach to develop a regional assessment tool
}

2 for bioenergy production

3 Ashma Vaidya ${ }^{a^{*}}$, Audrey L. Mayer ${ }^{a, b}$

4

$5 \quad{ }^{a}$ Department of Social Sciences, Michigan Technological University, 1400 Townsend Dr., $6 \quad$ Houghton, MI 49931, U.S.A

$7 \quad{ }^{b}$ School of Forest Resources and Environmental Science, Michigan Technological

8 University, 1400 Townsend Dr., Houghton, MI 49931, U.S.A

9

10 *Corresponding author. Email address: avaidya@ mtu.edu. 
Recent years have witnessed an upsurge in certification schemes and sustainability assessment tools for bioenergy, however these mechanisms are often too generic,

15 numerous and too broad for regional or local level implementation. Furthermore, these assessments are often weighted toward economic and environmental sustainability with less focus on social, cultural and institutional factors. This study was intended to overcome these limitations. We developed a community-driven regional assessment tool for forest-based bioenergy production in the Upper Peninsula of Michigan (USA). Stakeholders representing local landowners, farmers, township supervisors, timberland management companies, venture capitalists, government organizations and local interest groups generated a preliminary list of criteria and indicators (C\&I) in a series of focus groups and interviews, and narrowed the list using multiple criteria analysis (MCA) in a workshop. Participants ranked environmental protection as the most important and relevant sustainability criteria, although policy and governance, and institutional capacity were also weighted highly. The final set of C\&I consisted of 17 criteria and 31 indicators (in parentheses): Economic (6), Environmental (7), Social (8), Policy and regulations (4) and Institutional capacity (6). This set reflected the general balance across sustainability principles valued by the stakeholders. While expert-developed sustainability assessments are routinely biased toward easily quantifiable indicators, the indicators that were considered important and relevant by our participants included both quantitative as well as qualitative indicators, in almost equal proportions. This participatory MCA method identified criteria and indicators that reflect the regional context and the concerns of local

34 stakeholders, and data for many of these indicators are readily available.

Keywords: bioenergy, participatory, multiple criteria analysis, sustainability, sustainable assessment 


\section{$41 \quad$ 1. Introduction}

Growing interest of countries in the production and use of renewable energy,

43 particularly since the early 2000s (e.g. US Energy Independence and Security Act of

44 2007; EU Renewable Energy Directive 2009) has generated a rapid expansion of

45 biomass-based bioenergy production. In response, there has been a sharp increase in the

46 number of initiatives to monitor and standardize the production of bioenergy products

47 and their sustainability-related impacts [1]. These initiatives are generally motivated by

48 the need for international trade obligations and other considerations [2], with little regard

49 to local contexts [3].

50 Sustainability is an integrative function of environmental protection, economic

51 viability and social equity [4-8]. Sustainable bioenergy development entails context-

52 driven policy, regulations and institutional capacity $[9,10]$. Nevertheless, most

53 sustainability assessment frameworks for bioenergy neglect issues such as governance,

54 social impacts, and the linkages among global, national and local contexts $[3,10,11]$.

55 Van Dam et al. (2010) suggested that bioenergy assessments of developing countries are

56 generally motivated by socio-economic concerns while assessments in developed

57 countries focus more on economic and environmental principles of bioenergy production

58 [11]. Similarly, assessment tools used for micro and meso-scale assessments (e.g., Life

59 Cycle Assessments, Cost-Benefit Analysis, and Environmental Impact Assessment)

60 mostly focus on techno-economic and environmental aspects of bioenergy development,

61 largely failing to reflect socio-economic and other community concerns and contexts

62 [12]. A few global-scale sustainability assessments address these shortcomings and

63 incorporate all sustainability principles (such as Roundtable on Sustainable Biomaterials

64 (RSB), Roundtable on Sustainable Palm Oil (RSPO), Global Bioenergy Partnership

65 (GBEP), and International Organization for Standardization (ISO) etc.). However, the

66 variety of feedstocks, geographical regions, cultural contexts, logistic requirements, and

67 production processes make existing generic frameworks too broad and ambiguous for

68 practitioners to use at the grassroots level [3, 13-16]. This suggests the need for a

69 comprehensive framework for building sustainability assessments to address

70 sustainability goals at a variety of scales $[3,11,13,15]$. 
Bioenergy production is a complex system with multiple interconnected

72 components. An indicators-based sustainability assessment for bioenergy should be

73 holistic and systemic, incorporating the participation of experts and actors from all

74 components of the system $[16,17]$. This is possible only through an inductive,

75 collaborative and reflexive approach that involves all key stakeholders in the

76 development of the framework [13, 18]. Participation in decision-making processes by

77 key stakeholders and local experts can also enhance credibility, ownership, and context-

78 specificity of the interventions, which are all imperative in the pursuit of sustainable

79 bioenergy development [13].

80 This paper discusses the participatory development of a regional bioenergy

81 sustainability assessment, involving stakeholders from all key components of a potential

82 bioenergy production system. In the earlier phase of this study, we identified the interests

83 and values of key stakeholders in relation to regional bioenergy development. These

84 concerns and values were then translated into an extensive list of sustainability criteria

85 and indicators (C\&I) using an expert-assisted approach ${ }^{1}$ for a bioenergy production

86 system [10]. The main objective of this paper is to report the results from a stakeholder

87 workshop and Multiple Criteria Analysis (MCA) methods to narrow down the long list of

88 C\&I from the earlier phase into a comprehensive yet manageable set of sustainability

89 C\&I. In Section 2, we briefly discuss the different phases of the research, and techniques

90 used to collect and analyze data over the course of this study. In Section 3, we discuss our

91 research outcomes and present the final sustainability assessment framework. In Section

924 , we discuss the conclusions and limitations of our study.

\section{Methods}

Our study was conducted in the Western Upper Peninsula (WUP) of Michigan.

97 The immense exploitation of the forestlands in the late 1800s and the early 1900s by the

98 logging and mining industries had once left this region almost completely deforested

99 [20]. Following the rapid downsizing of these industries by the 1960s, the subsequent

\footnotetext{
${ }^{1}$ An expert-assisted approach is a participatory approach, which involves the elicitation of local knowledge to understand the local socio-ecological context. In this approach, experts only facilitate the process and avoid using pre-defined criteria and indicators to generate a sustainability framework [19].
} 
outmigration had a tremendous impact on the regional economy. In the intervening

101 decades the forests have regenerated, and currently more than $80 \%$ of the WUP land is forested [21]. The forest industry remains as an important part of the local economy and culture in the WUP. However, the youth population has continued to decline and the

104 WUP remains an aging population [22].

We divided the study into three distinct phases: I) stakeholder selection; II) qualitative development of C\&I; and III) preference elicitation using MCA techniques.

107 We accomplished stakeholder selection through stakeholder analysis [23]. We collected data using a combination of three different participatory techniques for the latter two phases: focus groups and interviews for phase II [10] and one workshop to accomplish phase III. Here we will limit our discussion to phases I and III of this study. The main purpose of the workshop was to solicit feedback using MCA techniques on the importance and relevance of C\&I generated from phase II, to generate a manageable, representative set of C\&I to be used as a sustainability assessment tool as the bioenergy industry develops in the WUP.

\subsection{Stakeholder selection}

We identified stakeholders using a number of sources, including professional networks, snowballing and Internet searches. We invited potential participants through physical mail and/or email, which conveyed a brief description about the project, their role in the study, time commitments required of them, and incentives for their participation in the project. 
Fig 1. Distribution of participants over different stakeholder groups: Participants were categorized into different stakeholder groups (representing different components of bioenergy production system) depending upon their affiliations. Some participants have been counted in more than one category, depending upon the number of stakeholder groups they represented.

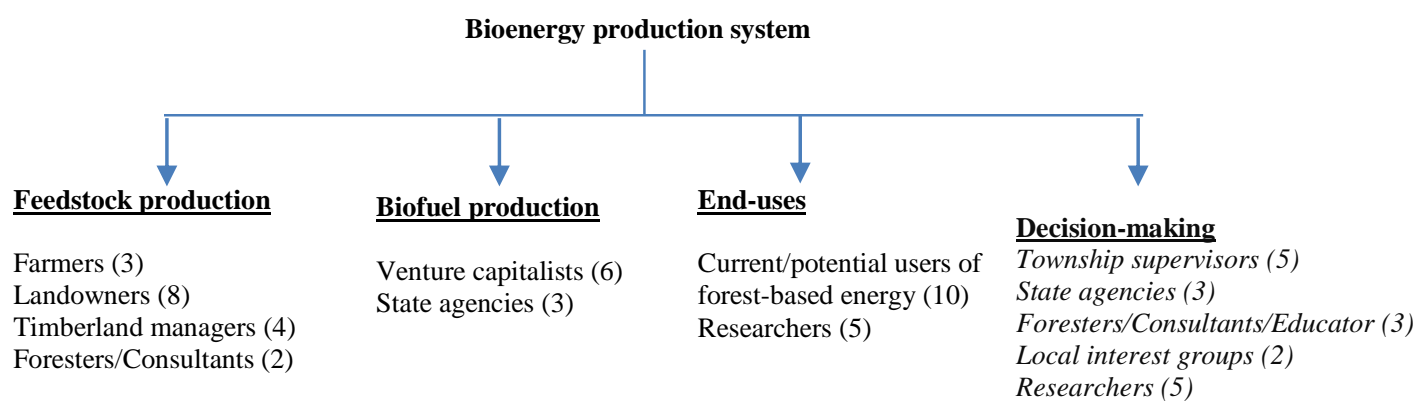

\subsection{Qualitative development of C\&Is}

This phase identified the concerns of the stakeholders and their information needs. In addition to data collected through focus group meetings and interviews, a literature review on sustainability assessments also contributed to the development of the preliminary list of C\&I. The literature review allowed us to partially validate our results from the focus groups and interviews, and highlighted the influence of the regional context on the sustainability goals of the community. Subsequently, we developed an extensive list of sustainability principles and criteria (and sub-criteria and indicators for some criteria) based on the framework described in [24] (see Appendix A).

\subsection{Preference elicitation: Stakeholder workshop}

Criteria that are widely used in the evaluation of sustainability indicators are: importance, relevance, practicality, reliability and their sensitivity to the changes caused by the system of concern [17, 25-27]. In our study, participants evaluated the preliminary set of sustainability criteria for their importance (to the participants) and relevance (to the wood-based bioenergy production in the WUP) at the stakeholder workshop. The evaluation of C\&I based on their sensitivity and practicality was beyond the scope of this study. 
Prior to the preference elicitation, we gave a PowerPoint presentation to

167 participants about the research activities conducted up to that point, expected outcomes of 168 the workshop, and the MCA techniques that participants would use to evaluate the 169 criteria and indicators. The presentation also included a brief introduction about the 170 project, objectives of the workshop agenda, purpose of the workshop, and the project as a 171 whole. The stakeholder workshop was held to accomplish this task. The workshop 172 followed three steps:

\subsubsection{Preparation}

2.3.1.1. Criteria and indicators: Not all criteria and indicators in the preliminary list were bioenergy-specific, and many of them reflected the general concerns of the participants as a community. On the other hand, some of the bioenergy-specific criteria and indicators were relevant to one group of stakeholders with little relevance to another group. For instance, 'land management opportunities for landowners' and 'professional consulting services for landowners and farmers' are clearly relevant to feedstock producers, while they are of little relevance to the bioenergy producers or potential consumers of the bioenergy products. Therefore, in order to make the assessments comprehensive and easy to work with for all participants, we rearranged the criteria and indicators in the preliminary list into two broad categories: general (for criteria that reflected the concerns

186 of the stakeholders as a community) and bioenergy-specific (for criteria that were reflective of participants' concerns as stakeholders of the bioenergy system). We further subdivided the categories based on specific concern areas (as shown in Fig 2) and assessed in different group structures (as discussed in Section 2.3.3) 
Fig 2. Rearrangement of criteria and indictors: Criteria and indicators in the preliminary list were rearranged so as to make it easier for participants to evaluate them using different assessment techniques at the workshop.

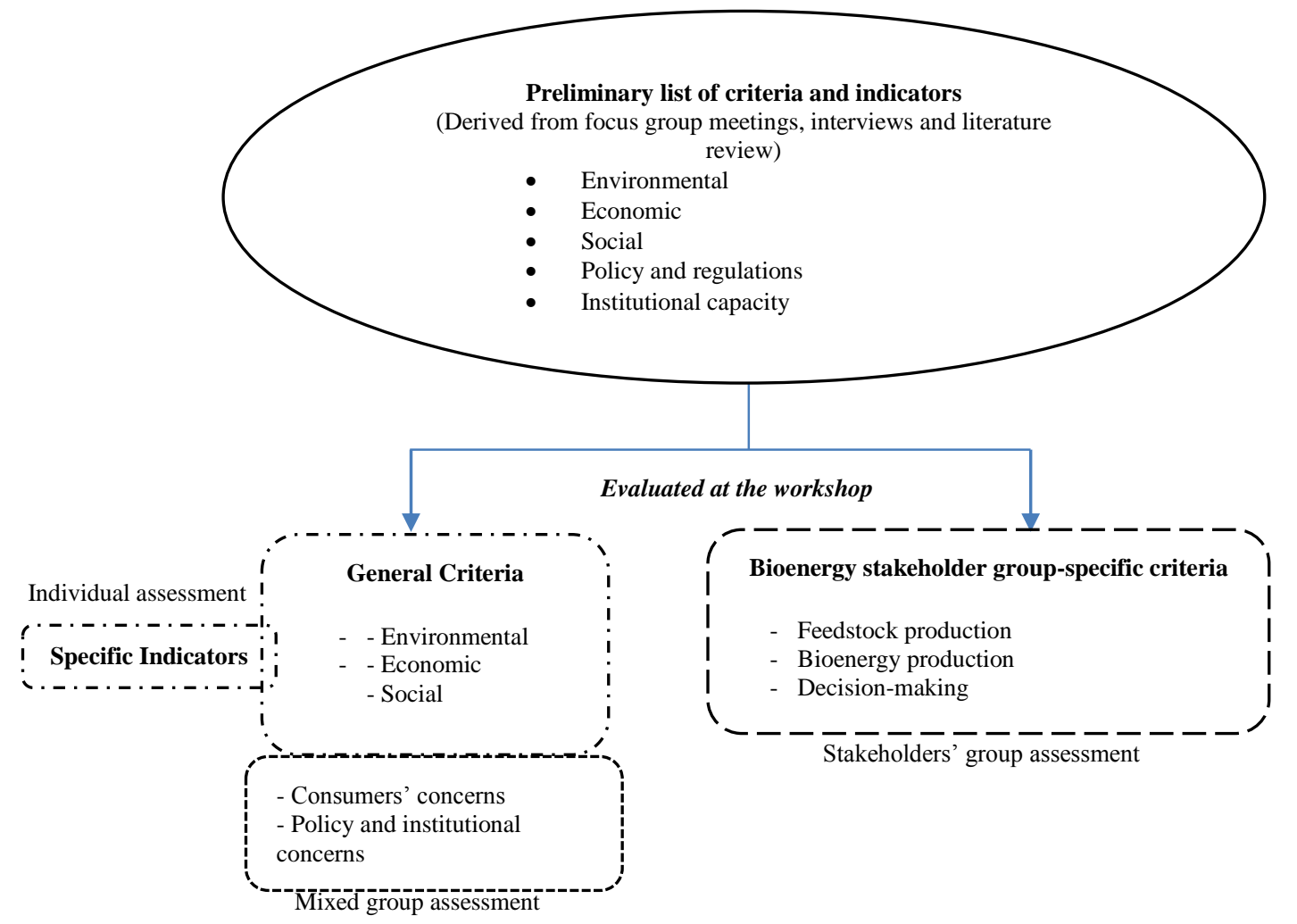

2.3.1.2. Participants: We invited all study participants (36 in total) who had participated in phase II to the half-day workshop. The invitation included a workshop agenda with a timeline and a list of activities planned for the workshop. Only 17 participants could attend the workshop, and were accompanied at the workshop by five researchers (new participants) working on different components of forest-based bioenergy development in the WUP. Fifteen of the invited participants expressed interest in participating in the workshop but could not due to time conflicts. We sent a survey package to record their preferences. The data collection package contained four key materials: a handout that explained MCA techniques, an assessment worksheet, and a glossary that briefly described all the criteria listed in the assessment sheet (see Appendix B for an example of

211 data collection worksheet). Out of those 15 participants, nine returned the worksheet.

212 Altogether 31 stakeholders participated in this phase. 


\subsubsection{Preference elicitation tools}

Multiple Criteria Analysis (MCA) was used to identify the most relevant and important C\&I for the sustainability assessment of bioenergy production in the WUP. MCA is a decision-making tool used when an evaluation process involves multiple, competing interests and objectives among diverse stakeholders. It has been used extensively as a decision-making tool in a wide range of resource management and planning projects $[28,29,30]$, including sustainable energy development and planning [17, 31-34]. MCA has also been used for a variety of other purposes, many of which include choosing between management alternatives or technology options against a set of pre-defined criteria [35-37]. In some cases it has been used to identify the optimal criteria or indicators to assess an emerging intervention or technology [17, 37, 38].

In our study, we used three different MCA techniques to elicit preferences from the stakeholders: Analytical Hierarchy Process or pairwise comparison ${ }^{2}$; ranking; and rating (for procedural details about these methods, refer to [28, 39]). We used these simple MCA techniques for preference elicitation over other more popular softwarebased MCA techniques [40], because: i) no special skill or technology is required to use them and they are easy to learn and understand, which was important in our case as it involved participants (or 'decision-makers') from diverse backgrounds (i.e. both scientific and non-scientific); ii) it can be used to evaluate both quantitative and qualitative criteria and indicators, and iii) these methods require relatively less time for decision-making [28, 30, 40, 41] Since pairwise comparison, outranking and rating are relatively easier to use than other software-based techniques, it can encourage a greater participation of stakeholders from a wide range of backgrounds to aid decision-making processes. For this reason, MCA is often associated with transparency and credibility [28, $39,42]$.

Participants used pairwise comparison to make one-on-one comparisons between criteria [28]. We calculated pairwise ranks, and aggregate weights using Microsoft Excel and Analytical Hierarchy Process formulae adapted from [28, 39, 43]. Participants evaluated different options at three different levels or hierarchies: principles, criteria and sub-criteria/indicators. However, pairwise comparison was used only at principles and

\footnotetext{
${ }^{2}$ Where the scoring or ranking is derived from a one-to-one comparison between criteria.
} 
244 criteria level because of the implicit requirement for more information to make

245 comparison between indicators. In pairwise ranking, only the comparisons that had a

246 consistency ratio $(\mathrm{CR}) \leq 0.1$ were included in the calculation of the average ranks. For

247 weighted averages, $n$ (total number of samples) was between 10-13 for each set of

248 pairwise comparison, after eliminating the matrices with $\mathrm{CR}>0.1$. Participants used

249 rating and ranking methods for all bioenergy-specific criteria and indicators. Multiple

250 techniques were used to assess criteria and indicators whenever possible, in order to

251 examine consistency in decision-making. Criteria and sub-criteria with the highest

252 aggregate weights were listed in the final set.

253

\subsubsection{Assessment of $C \& I$}

We divided the workshop exercise into three segments: individual assessment, stakeholders' group assessment, and mixed-group assessment. We encouraged participants to write down notes on terms and phrases that they found difficult to understand, and to note C\&I that they felt were redundant or missing from the list.

\subsubsection{Individual assessment: First, on their own, participants ranked and rated} sustainability principles (i.e. environmental protection, social justice and equity, economic benefits, policy and regulations, and institutional capacity), and a list of environmental and socio-economic criteria and indicators. Participants evaluated these principles and C\&Is based on their relative importance and relevance to the forest-based bioenergy industry in the context of the WUP, using pairwise comparison and rating methods. To make the assessment less time-intensive for the participants, use of pairwise comparison (which usually takes longer than the other two MCA techniques) was limited to general criteria under three primary sustainability principles: environmental, economic and social. Participants also used a rating method to evaluate the criteria based on their relevance and importance. They rated indicators for social, economic and environmental sustainability that were validated through a literature review. We designed this assessment based on the assumption that local stakeholders' knowledge and perceptions would lead to $C \& I$ that are more reflective of the local context and interests of the community. We used individual assessment for general socio-economic and 
275 environmental C\&I because of their (large) numbers and relevance to all stakeholders.

276 Running them through group assessments may have entailed longer discussion times,

277 which in turn could have affected the effectiveness and efficiency of the process. Despite

278 the willingness shown by our participants to contribute to this study, conflicting

279 schedules and travel distance to the workshop made time one of our limiting factors.

\subsubsection{Mixed group assessment: Next, we sorted all participants to create four}

282 heterogeneous groups of stakeholders. This group evaluated criteria and indictors under

283 'Consumers' concerns' and 'Policy and institutional concerns' under the 'General

284 criteria' category in Fig 2. All groups used ranking as well as rating systems to evaluate

285 the given list of C\&Is for their relevance and importance. We structured the group

286 assessment based on the assumption that 'Consumers' concerns' and 'General policy and

287 institutional concerns' were relevant to all stakeholders, because everyone plays the role

288 of consumer and occasionally a decision-maker.

289

290

2.3.3.3. Stakeholder group assessment: Finally, we categorized our participants into three homogenous ${ }^{3}$ stakeholders' groups (feedstock production, biofuel production, decision makers) depending on the components of the bioenergy production system that they represented. They worked with the criteria that were specific to the components for their group. For example, the 'feedstock production' group evaluated criteria such as 'location of the plantation', 'land management opportunities for landowners', 'professional consulting services for landowners and farmers', and 'long-term contracts between buyers of feedstock and the growers of feedstock'. structures by our participants at the workshop, the results from all assessments have been

\footnotetext{
3 'Homogeneity' has been stressed in the structuring of the groups because a homogenous group is more likely to encourage unhindered communication and smooth exchange of information [44].
} 
combined and rearranged in the final set under five different sustainability principles:

305

306 economic, environmental, social, governance, and institutional capacity. While most sustainability discourse is primarily focused on social, environmental and economic dimensions, our participants also assessed 'Policy \& regulations' and 'Institutional capacity' as important and relevant sustainability principles (see Fig. 3). They were rated and ranked similarly (in terms of both importance and relevance) to social and economic principles. 

data for them (also included in tables below).

\subsubsection{Economic criteria}

Most of the economic indicators chosen as the most important and relevant by our participants have been widely used in the literature $[12,38,45]$. However, the use of stakeholders (Table 1).

333

334

335

Table 1. Final set of economic $C \& I^{5}$

\begin{tabular}{|l|l|c|l|}
\hline Criteria & Sub-criteria/Indicators & $\begin{array}{l}\text { Direction to } \\
\text { sustainability }\end{array}$ & Potential data sources \\
\hline Local economy & Unemployment rate & $\begin{array}{r}<\text { baseline } \\
\left(\text { e.g. } 5.4 \%{ }^{6}\right)\end{array}$ & US Bureau of Labor Statistics (US BLS) \\
\cline { 2 - 5 } & $\begin{array}{l}\text { Local revenue (per capita } \\
\text { personal income in USD) }\end{array}$ & $\begin{array}{c}>\text { baseline } \\
\left(\text { e.g. } 34,685^{7}\right)\end{array}$ & US Bureau of Economic Analysis (US BEA) \\
\hline Resource efficiency & $\begin{array}{l}\text { Wood biomass } \\
\text { availability/price }\end{array}$ & $\begin{array}{l}\text { baseline } \\
\text { investment (EROI) }\end{array}$ & $\begin{array}{l}\text { US Department of Agriculture (USDA)- Forest Inventory } \\
\text { and Analysis, MI-Department of Natural Resources }\end{array}$ \\
\cline { 2 - 5 } & Fossil energy return on & $>$ baseline \\
\cline { 2 - 5 } & Use of local resources & $\begin{array}{l}\text { Michigan Forest Biofuels Research, US Department of } \\
\text { Energy (USDoE)-Biomass Program }\end{array}$ \\
\hline Profitability & Return over investment & $\uparrow$ & $\begin{array}{l}\text { Survey of bioenergy plant } \\
\text { Techno-economic assessments (Ongoing researches) }\end{array}$ \\
\hline
\end{tabular}

336

337

338

\subsubsection{Environmental criteria}

Although our participants rated environmental sustainability as the most important of all criteria, they were not able to identify, recommend, or rate environmental indicators easily. Many participants expressed difficulty in understanding scientific terminologies related to these indicators, and some environmental indicators were not rated. Under such circumstances, non-responses were not counted into the calculation of

\footnotetext{
${ }^{5}$ When data were not available, the relationship has been indicated as $\uparrow$ or $\downarrow$ or $=$ signs to indicate whether they should increase/improve, decrease/decline or remain intact/balanced, as compared to the baseline. For qualitative indicators, relationships have been indicated as $\sqrt{ }$ (for 'Yes' or affirmative) and $\mathrm{X}$ (for 'No' or negative) measurements.

${ }^{6}$ Estimate for WUP from September [46].

${ }^{7}$ Estimate from [47].

${ }^{8}$ Estimate varies depending on boundaries, subsidies, externalities, and production system [48].
} 
344 average ratings. Therefore, most of the environmental indicators presented in the table

345 have been validated further using the sustainable bioenergy literature (Table 2).

346

347

348

Table 2. Final set of environmental C\&I

\begin{tabular}{|c|c|c|c|}
\hline Criteria & Sub-criteria /Indicators & $\begin{array}{c}\text { Direction to } \\
\text { sustainability }\end{array}$ & Potential sources of data \\
\hline \multirow[t]{2}{*}{ Water quality } & Nutrient concentration $(\mathrm{N}, \mathrm{P})$ & $\downarrow$ & United States Geological Survey (USGS), MSU Extension \\
\hline & $\begin{array}{l}\text { Herbicide/pesticide } \\
\text { concentration }\end{array}$ & $\downarrow$ & United States Geological Survey (USGS), MSU Extension \\
\hline \multirow[t]{2}{*}{ Air quality } & $\begin{array}{l}\text { Particulate matters (PM), CO, } \\
\text { SOx, NOx }\end{array}$ & $\downarrow$ & $\begin{array}{l}\text { United States Environmental Protection Agency (US-EPA), } \\
\text { EPA (National Emissions Inventory, Monitoring services) }\end{array}$ \\
\hline & Greenhouse gases & $\downarrow$ & EPA (National Emissions Inventory, Monitoring services) \\
\hline \multirow[t]{2}{*}{ Soil quality } & Soil erosion/soil compaction & $\downarrow$ & USGS, United States Department of Agriculture (USDA) \\
\hline & Nutrient & $=$ baseline & USGS, USDA \\
\hline Ecosystem & $\begin{array}{l}\text { Avoid invasive species/ Use } \\
\text { native species }\end{array}$ & $\sqrt{ }$ & $\begin{array}{l}\text { Michigan Department of Natural Resources (MI-DNR), } \\
\text { USDA }\end{array}$ \\
\hline
\end{tabular}

\subsubsection{Social criteria}

The social criteria had a balance of quantitative and qualitative indicators (Table 3). Although social indicators in general have been overlooked in sustainability

354 assessments, social indicators for criteria such as food security, transparency and

355 participation are increasingly popular in sustainability assessments for energy systems [3,

$35612,38]$. Indicators related to participation and transparency were also weighted highly in

357 our study; however, food security was not weighted as highly for relevance.

Table 3. Final set of social C\&Is

\begin{tabular}{|l|l|c|l|}
\hline Criteria & Sub-criteria /Indicators & $\begin{array}{l}\text { Direction to } \\
\text { sustainability }\end{array}$ & Potential sources of data \\
\hline Participation & $\begin{array}{l}\text { Key stakeholders' participation in decision } \\
\text { making }\end{array}$ & $\sqrt{ }$ & Stakeholder survey \\
\hline Transparency & Public availability of management plan & $\sqrt{ }$ & $\begin{array}{l}\text { Stakeholder survey, Monitoring } \\
\text { reports }\end{array}$ \\
\cline { 2 - 5 } & $\begin{array}{l}\text { Communication of research outcomes and long- } \\
\text { term impacts }\end{array}$ & $\sqrt{ }$ & Stakeholder survey \\
\hline Work condition & Workers safety & $\sqrt{ }$ & Survey, Project plan \\
\hline Recreational values & Recreational activities/areas & $=$ & DNR, WUPPDR, Survey \\
\hline
\end{tabular}




\begin{tabular}{|l|l|c|l|}
\hline $\begin{array}{l}\text { Educational/capacity } \\
\text { building }\end{array}$ & Skill transfer and training opportunities & $\uparrow$ & Survey, Project plan \\
\hline Consumer concerns & Reliability/consistent supply of the product & $\sqrt{ }$ & Market survey \\
\cline { 2 - 4 } & Environment-friendly & $\uparrow$ & $\begin{array}{l}\text { Market survey, Techno-economic } \\
\text { assessments }\end{array}$ \\
\hline
\end{tabular}

361

362

363

\subsubsection{Criteria for governance and institutional capacity}

This set represents policy, institutional building and management concerns of the participants (Table 4). All indicators in this set are qualitative.

\section{Table 4. Final set of governance, and institutional capacity related C\&Is}

\begin{tabular}{|c|c|c|c|c|}
\hline $\begin{array}{c}\text { Sustainability } \\
\text { Principles }\end{array}$ & Criteria & $\begin{array}{l}\text { Sub-criteria } \\
\text { /Indicators }\end{array}$ & $\begin{array}{c}\text { Direction to } \\
\text { sustainability }\end{array}$ & Potential sources of data \\
\hline \multirow[t]{4}{*}{ Governance } & \multirow[t]{2}{*}{$\begin{array}{l}\text { Regulatory } \\
\text { policies }\end{array}$} & $\begin{array}{l}\text { Pay all legally prescribed } \\
\text { fees/royalties/taxes }\end{array}$ & $\sqrt{ }$ & Ex post stakeholder survey \\
\hline & & $\begin{array}{l}\text { Compliance to state } \\
\text { standards and regulations }\end{array}$ & $\sqrt{ }$ & Monitoring agencies \\
\hline & \multirow{2}{*}{$\begin{array}{l}\text { Precautionary } \\
\text { policies and } \\
\text { support } \\
\text { mechanisms }\end{array}$} & $\begin{array}{l}\text { Compliance to } \\
\text { sustainable harvesting } \\
\text { practices }\end{array}$ & $\sqrt{ }$ & $\begin{array}{l}\text { Ex post stakeholder survey, Government } \\
\text { monitoring agency }\end{array}$ \\
\hline & & $\begin{array}{l}\text { Protection of } \\
\text { landowners' rights }\end{array}$ & $\sqrt{ }$ & Ex post landowner survey \\
\hline \multirow{6}{*}{$\begin{array}{l}\text { Institutional } \\
\text { capacity }\end{array}$} & \multirow[t]{3}{*}{ Logistics } & Water source & $\sqrt{ }$ & Baseline study \\
\hline & & Technical expertise & $\sqrt{ }$ & Baseline study \\
\hline & & $\begin{array}{l}\text { Consistent supply of } \\
\text { feedstock/products }\end{array}$ & $\sqrt{ }$ & Baseline study, ex post market survey \\
\hline & \multirow{3}{*}{$\begin{array}{l}\text { Management } \\
\& \text { monitoring }\end{array}$} & Regular monitoring & $\sqrt{ }$ & Monitoring agencies \\
\hline & & $\begin{array}{l}\text { Residue management } \\
\text { and utilization }\end{array}$ & $\sqrt{ }$ & Project plan, Monitoring reports \\
\hline & & $\begin{array}{l}\text { Colocation of } \\
\text { biorefineries in existing } \\
\text { facilities }\end{array}$ & $\sqrt{ }$ & Project plan, Monitoring reports \\
\hline
\end{tabular}

\subsection{Measurable sub-criteria/indicators and eliminations}

From the final list of C\&Is, the indicators that were rated lower were eliminated, particularly if the variance for the calculated means were also smaller [28]. For indicators with no available data, we chose the indicator rated and/or ranked next highest with available data. 
While some C\&Is preferred by the stakeholders are clearly measurable and are supported by existing databases, others (mostly concerning social, policy and management issues) were inherently qualitative and their measurement would require additional data collection through qualitative research methods. For such criteria rated and ranked highly important and relevant (such as 'Compliance to sustainable harvesting practice', 'Pay all applicable and legally prescribed fees/royalties/taxes'), existing databases were not helpful. For these, routine monitoring and evaluation by the state agencies will be necessary.

\subsection{Interesting criteria/indicators}

Interestingly, some of the sustainability indicators ('benefits from external trade', 'infrastructure development in the region', 'youth population in the region' and indicators related to food security) that were frequently discussed in focus groups and interviews were rated lower than others in the workshop. For example, 'food security' was rated as important and relevant at the criteria-level (see Supplemental Material), but its indicators (i.e. food price, change in local agricultural land area, restrict use of agricultural land for biofuel production, availability of agricultural land) received low ratings for their relevance to wood-based bioenergy production. During the focus group and interviews, participants associated forest-based bioenergy more with residues and wastes from forestbased industries, than with plantations and food crops.

External trade was brought up as an important concern by venture capitalists in focus groups and interviews. However, at the workshop it received the lowest aggregate weighting for relevance and importance as an economic criterion. Indicators related to employment, energy security, resource efficiency and use of local resources were rated and ranked higher in the assessment (in both criteria as well as indicator level assessments) than those related to external trade. This may suggest that stakeholders were more concerned about ensuring economic benefits to the community through self-reliance in energy and local employment, than through expansion of external trade.

Similarly, in focus groups and interviews, the loss of the youth population for jobs elsewhere was frequently cited as a negative effect of the shrinking economy. However, relative weightings suggested that participants on average considered youth population to 
407 be the least relevant indicator of 'local economy'. The fact that 'employment' was rated

408 the highest in the given criteria suggests that participants may have viewed 'youth

409 population' as redundant indicator in the list, hence rated lower.

\subsection{Difficult indicators}

A few participants expressed confusion in understanding terms such as 'Institutional capacity', 'Transparency' and 'Compliance'. Participants particularly struggled with rating indicators under environmental criteria; at least 6 workshop participants expressed difficulty in understanding or assessing the environmental indicators, despite the assistance of the facilitators and the glossary provided to each participant at the workshop. Environmental indicators are the most extensively used sustainability indicators in the literature for assessing sustainability of bioenergy production [11]. At the focus groups and interviews, however, most participants hesitated to provide specific indicators for environmental criteria that they perceived as important, citing their lack of awareness about the potential impacts of bioenergy production on the environment. The difficulty among the participants in evaluating environmental indicators may be due to these indicators being expert-driven, and laden with technical terminologies.

In a similar study for sustainable development indicators for Marine Protected Areas, Marques et al. (2013) attributed unanswered questions in their survey by stakeholders to either a lack of knowledge about the matter, or a lack of interest in the given issue [49]. Our interaction with participants at the workshop suggested that the former might be the case in this study.

\subsection{Variability in judgments}

Participants were allowed to choose their own methods to reach consensus and provide a collective judgment in the given worksheet. These methods either involved averaging out the individually assigned rankings and ratings within the group, or making collective decisions preceded by intense discussions.

The large variance (standard error) across almost all criteria and indicators could originate from two sources. First, some of the participants struggled with the data 
438 collection tool, and the large standard errors could reflect some confusion over the tool

439 itself. Based on the consistency index, participants were found to be less comfortable and

440 consistent in making judgments using pairwise comparison methods. Our results also

441 suggest that on the whole, our participants saw little difference between importance and

442 relevance, and perhaps one of the two can be omitted in the future. Second, there could

443 be wide disagreement among stakeholders (or even within stakeholder groups) regarding

444 the relative utility of criteria and indicators; in this case, the standard error provides a

445 measure of the diversity within our sample group.

446 Finally, in the case of a few criteria and indicators (such as 'Subsidies and taxes'),

447 the high priority may reflect a diversity of opinion and possible interpretations; in these

448 cases, one must go back to the conversations in the focus groups and interviews.

449 'Subsidies/tax incentives' was one of the most contentious issues: some participants

450 expressed that bioenergy production would need to be subsidized in order to be

451 successful, while others felt that a bioenergy industry should not receive subsidies to be

452 considered 'sustainable' (in the sense of persisting in the long term). Still other

453 participants considered subsidies to the fossil industry to be an important issue in

454 bioenergy sustainability, but were arguing for the elimination of all subsidies. All of these

455 positions consider subsidies to be an important issue, but for different reasons. Therefore,

456 the high priority of "subsidies and taxes" should not be interpreted as uniform support for

457 subsidizing the bioenergy industry, for example. This indicator was omitted from the

458 final list of C\&Is due to a lack of consistency in the relevant judgments.

\subsection{Threshold and directions}

Sustainability assessment is a tool which should contribute to a better

understanding of contextual details, and influence actions that can contribute to meeting sustainability objectives of the key stakeholders [16]. A common limitation of many generic sustainability assessments is that they fail to provide direction and thresholds that are imperative for the measurement and interpretation of sustainability indicators [13].

466 Efroymson et al. (2013; p. 302) argue that general sustainability assessments should be 467 treated as a starting point, but local concerns and objectives should guide the 'selection, 468 measurement and interpretation' of sustainability indicators for biofuel systems [15]. We 
selected sustainability indicators based on local concerns and stakeholders' values, and

470 we are able to provide a direction for improvement based on the characteristics and

471 function of each indicator (Table 1-4). However, setting thresholds (which is key to the

472 interpretation of sustainability indicators) is beyond the scope of this study.

473

\subsection{Sustainability assessment and its policy implications}

The Michigan Public Act 295 (2008) stipulated that electric providers in the state have ten percent of electricity produced from qualified renewable energy sources by 2015 [50]. Until 2012, wood-based biomass was the primary contributor to the Michigan renewable energy portfolio (RPS). In 2014, biomass contributed 35\% of the Michigan

479 RPS compliance target [51]. However, of the three renewable energy projects under the Michigan RPS in the UP, only one project uses biomass as a source of renewable energy [50]. The only biomass-driven energy plant in the WUP (in L'Anse, MI) has recently come under public scrutiny for the use of environmentally hazardous feedstock [52]. Similarly, a demonstration facility located in Northeast Michigan halted its wood-based ethanol production due to "the low ethanol price environment, the small size of the precommercial facility, and the limited feedstock supply" (see http://www.alpenabiorefinery.com/). Although the utility companies with renewable energy contracts in Michigan claim that they have met the 2015 compliance target, they have supported removing the mandates [53]. The Renewable Energy Amendment (2012) that proposed an increased renewable energy target of 25\% to be met by 2025 (Proposal 3) was defeated at the state's electorate. Nevertheless, Li et al. (2014) suggest that renewable energy is widely supported by the Michigan public and the defeat of Proposal 3 does not reflect public opinion regarding renewable energy [54]. renewable resources and in learning about the potential for wood-based bioenergy. Our stakeholders were very keen on participation and transparency, expressing a desire for more communication about research progress and policy interventions. With reference to bioenergy production, Becker et al. (2009) suggest that not only benefits and promises,

499 Conversely, public outreach and research are generally the least-used policy interventions 
500 by states for the development of bioenergy industries [56]. A stakeholder-driven regional

501 sustainability assessment tool can play an important role in informing policy-makers

502 about the key areas that may require intervention for the sustainable development of this

503 industry.

504

505

\section{4. Conclusion}

Finally, stakeholders' participation was the keystone of this study; it provided

509 multiple opportunities to the researchers involved to interact with stakeholders and to

510 define sustainability in relation to bioenergy production. Although the C\&I were derived

511 from stakeholders' concerns and perceptions, allowing participants to provide feedback

512 was important to further ensure the credibility and validity of our study findings. The

513 workshop provided an opportunity for researchers to share research outcomes and

514 progress with the participants.

515 Involving stakeholders and local experts in the project (from planning and design

516 to evaluation of the C\&I) also allowed us (the researchers) to familiarize ourselves with

517 the local terms, contexts and, stakeholders' interests and values. This is important to

518 improve the likelihood that the framework is adopted and implemented by local

519 practitioners and policy makers as the bioenergy industry develops in the region.

520 However, it may be difficult to collect data for the qualitative indicators that we

521 recommend, particularly those related to governance and institutional capacity. Further

522 work may be necessary to identify methodological requirements for the collection of

523 relevant data. Furthermore, it may be difficult to monitor these qualitative data over time

524 if no one agency is responsible for collecting and monitoring these data. 


\section{Acknowledgments}

528 We would like to thank our study participants for their time and insights, and two 529 anonymous reviewers for comments which greatly improved this manuscript. This work 530 was supported by National Science Foundation grant \#1230803. 


\section{References}

532 [1] Van Dam J, Junginger M, Faaij A, Jürgens I, Best G, Fritsche U. Overview of recent developments in sustainable biomass certification. Biomass Bioenerg 2008;32(8):749-80.

[2] Elbehri A, Segerstedt A, Liu P. Biofuels and the sustainability challenge: A

[4] Burton I. Report on reports: Our common future: The world commission on environment and development. Environment: Science and Policy for Sustainable Development 1987;29(5):25-9.

[5] Dixon JA, Fallon LA. The concept of sustainability: origins, extensions, and usefulness for policy. Soc Natur Resour 1989;2(1):73-84.

[6] United Nations Conference on Environment and Development (UNCED). Earth Summit Agenda 21. The United Nations Programme of Action from Rio. [Internet]. New York (USA): United Nations. 1992. [cited 2015 Nov 30]. Available from: http://www.un.org/esa/dsd/agenda21/index.shtml

[7] Gibson RB. Beyond the pillars: sustainability assessment as a framework for effective integration of social, economic and ecological considerations in significant decision-making. J Env Assmt Pol Mgmt 2006;8(03):259-280.

[8] Mayer AL. Strengths and weaknesses of common sustainability indices for multidimensional systems. Environment International 2008;34:277-91 
[9] McCormick K. Supply chain coordination under uncertainty. In: Choi TM, Cheng TCE, editors. Bioenergy systems and supply chains in Europe: conditions, capacity and coordination. Berlin: Springer; 2011. p. 545-62.

[10] Vaidya A, Mayer AL. (In Press). Criteria and indicator for a bioenergy production industry identified via stakeholder participation. Int J Sust Dev World.

[11] Van Dam J, Junginger M, Faaij AP. From the global efforts on certification of bioenergy towards an integrated approach based on sustainable land use planning. Renew Sust Energ Rev 2010;14 (9):2445-72.

[12] Buytaert V, Muys B, Devriendt N, Pelkmans L, Kretzschmar JG, Samson R. Towards integrated sustainability assessment for energetic use of biomass: A state of the art evaluation of assessment tools. Renew Sust Energ Rev 2011;15(8):3918-33.

[13] Lewandowski I, Faaij AP. Steps towards the development of a certification system for sustainable bio-energy trade. Biomass Bioenerg 2006;30(2):83-104.

[14] Van Dam J, Junginger M. Striving to further harmonization of sustainability criteria for bioenergy in Europe: Recommendations from a stakeholder questionnaire. Energ Policy 2011;39(7):4051-66.

[15] Efroymson RA, Dale VH, Kline KL, McBride AC, Bielicki JM, Smith RL, et al. Environmental indicators of biofuel sustainability: what about context? Environ Manage 2013;51(2):291-306.

[16] Dale VH, Efroymson RA, Kline KL, Davitt MS. A framework for selecting indicators of bioenergy sustainability. Biofuel Bioprod Bior 2015;9(4):435-46.

[17] Buchholz T, Rametsteiner E, Volk TA, Luzadis VA. Multi criteria analysis for bioenergy systems assessments. Energ Policy 2009;37(2):484-95. 
[18] Podger D, Hoover E, Burford G, Hak T, Harder MK. Revealing values in a complex environmental program: a scaling up of values-based indicators. J Cleaner Prod. In Press. sustainability assessments for natural resource management. Int J Sust Dev World. 2014;21(4):369-79.

[20] Hamel J, MacKay M, Price DL, Jones SL. Western Upper Peninsula Regional State Forest Management Plan. Michigan (USA): Forest Resources Division and Wildlife Division, Michigan Department of Natural Resources; 2013 December.

[21] Mayer AL, Rouleau MD. ForestSim model of impacts of smallholder dynamics: Forested landscapes of the Upper Peninsula of Michigan. International Journal of Forestry Research 2013;Article ID 520207:p.13.

[22] United States Census. Center of Population. [Internet]. 2010. [cited on 2015 Sep 21]. Available from: http://www.census.gov/2010census/data/center-ofpopulation.php

[23] Reed MS, Graves A, Dandy N, Posthumus H, Hubacek K, Morris J, Prell C, Quinn CH, Stringer LC. Who's in and why? A typology of stakeholder analysis methods for natural resource management. J Environ Manage 2009;90(5):193349.

[24] Prabhu R, Colfer CJP, Dudley RG. Guidelines for developing, testing and selecting criteria and indicators for sustainable forest management: a C\&I developer's reference. Vol. 1. Bogor (Indonesia): Center for International Forestry Research; 1999.

[25] Reed MS, Fraser ED, Dougill AJ. An adaptive learning process for developing and applying sustainability indicators with local communities. Ecol Econ 2006:59(4):406-418. 
[26] McBride AC, Dale VH, Baskaran LM, Downing ME, Eaton LM, Efroymson RA, et al. Indicators to support environmental sustainability of bioenergy systems. Ecol Indic 2011;11(5):1277-89.

[27] Hák T, Moldan B, Dahl AL editors. Sustainability indicators: a scientific assessment. Vol 67. Washington: Island Press; 2012.

[28] Mendoza GA, Prabhu R. Multiple criteria decision making approaches to assessing forest sustainability using criteria and indicators: a case study. Forest Ecol Manag 2000;131(1):107-26.

[29] Uhde B, Hahn WA, Griess VC, Knoke T. Hybrid MCDA Methods to Integrate Multiple Ecosystem Services in Forest Management Planning: A Critical Review. Environ Manage 2015;56:373-88.

[30] Schmoldt DL, Kangas J, Mendoza GA. Basic principles of decision making in natural resources and the environment. In The Analytic Hierarchy Process in Natural Resource and Environmental Decision Making, pp. 1-13. London (UK): Kluwer Academic Publishers; 2001.

[31] Pohekar SD, Ramachandran M. Application of multi-criteria decision making to sustainable energy planning — a review. Renew Sust Energ Rev 2004;8(4):36581.

[32] Kowalski K, Stagl S, Madlener R, Omann I. Sustainable energy futures: Methodological challenges in combining scenarios and participatory multicriteria analysis. Eur J Oper Res 2009;197(3):1063-74.

[33] Wang JJ, Jing YY, Zhang CF, Zhao JH. Review on multi-criteria decision analysis aid in sustainable energy decision-making. Renew Sust Energ Rev 2009;13(9):2263-78.

[34] Scott JA, Ho W, Dey PK. A review of multi-criteria decision-making methods for bioenergy systems. Energy 2012;42(1):146-56. 
[35] Doukas HC, Andreas BM, Psarras JE. Multi-criteria decision aid for the formulation of sustainable technological energy priorities using linguistic variables. Eur J Oper Res 2007;182(2):844-55.

[36] Evans A, Strezov V, Evans TJ. Sustainability considerations for electricity generation from biomass. Renew Sust Energ Rev 2010;14(5):1419-27.

[37] Terrados J, Almonacid G, Hontoria L. Regional energy planning through SWOT analysis and strategic planning tools: Impact on renewables development. Renew Sust Energ Rev 11 2007;(6):1275-87.

[38] Kurka T, Blackwood D. Participatory selection of sustainability criteria and indicators for bioenergy developments. Renew Sust Energ Rev 2013;24:92-102.

[39] Saaty TL. Fundamentals of decision making and priority theory with the analytic hierarchy process Vol. VI of the AHP series. Pittsburg (PA): RWS Publications; 2000.

[40] Myšiak J. Consistency of the results of different MCA methods: a critical review. Environment and Planning C: Government and Policy. 2006;24(2):25777.

[41] Kurka T. Application of the analytic hierarchy process to evaluate the regional sustainability of bioenergy developments. Energy 2013;62:393-402.

[42] Mendoza GA, Prabhu R. Combining participatory modeling and multi-criteria analysis for community-based forest management. Forest Ecology and Management. Forest Ecol Manag 2005;207(1):145-56.

[43] Moore JH, Weatherford LR. Decision Modeling with Microsoft Excel. $6^{\text {th }}$ Edition, Prentice-Hall. 2001.

[44] Prell C, Hubacek K, Reed M. Stakeholder analysis and social network analysis in natural resource management. Soc Nat Resour 2009;22(6):501-18. 
[45] Dale VH, Efroymson RA, Kline KL, Langholtz MH, Leiby PN, Oladosu GA, et al. Indicators for assessing socioeconomic sustainability of bioenergy systems: a

663

664 short list of practical measures. Ecol Indic 2013;26:87-102.

[46] United States Bureau of Labor Statistics. Databases, tables \& calculators by subject. [Internet]. 2015. [cited on 2015 Nov 18]. Available from:

http://www.bls.gov/data/\#unemployment

[47] United States Bureau of Economic Analysis. Regional data: GDP and personal income. [Internet]. 2014. [cited on 2015 Nov 18]. Available from: http://www.bea.gov/iTable/index regional.cfm

[48] Townsend JM, Hall CAS, Volk TA, Murphy D, Ofezu G, Powers B, et al. Energy Return on Investment (EROI), liquid fuel production, and consequences for wildlife. In: Gates JE, Trauger DL, Czech B, editors. Peak oil, economic growth, and wildlife conservation. New York: Springer; 2014. p. 29-61.

[49] Marques AS, Ramos TB, Caeiro S, Costa MH. Adaptive-participative sustainability indicators in marine protected areas: Design and communication. Ocean Coast Manage 2013;72:36-45.

[50] Quackenbush JD, White GR, Talberg SA. Report on the implementation of the P.A. 295 renewable energy standard and the cost-effectiveness of the energy standards. [Internet]. Lansing (MI): Michigan Public Service Commission, Department of Licensing and Regulatory Affairs; 2015. [cited on 2015 Dec 1]. Available from: http://www.michigan.gov/documents/mpsc/PA_295_Renewable_Energy_48142 3 7.pdf

[51] Energy Information Administration (EIA) Michigan: State profile and energy estimates [Internet]. Washington D.C.: United States Department of Energy [updated 2015 March 19; cited 2015 Dec 01]. Available from: http://www.eia.gov/state/?sid=MI 
[52] Roblee D. 2015. L'Anse-Warden biomass power plant draws EPA attention. [Internet]. The Daily Mining Gazette. 2015 Nov 30. [cited on 2015 Dec 1]. Available from:

http://www.mininggazette.com/page/content.detail/id/549619/L-Anse-Wardenbiomass-power-plant-draws-EPA-attention.html?nav=5006

[53] VanHulle L. Michigan utilities want to end renewable energy mandate. Bridge Magazine/Crain's Detroit Business. [Internet]. 2015. [cited on 2015 Dec 1]. Available from: http://bridgemi.com/2015/10/michigan-utilities-want-to-endrenewable-energy-mandate/

[54] Li F, Solomon BD, Wellstead AM. Michigan's RPS ballot defeat: A policy failure or success? Energy Strategy Reviews 2014;5:78-87.

[55] Becker DR., Skog K, Hellman A, Halvorsen KE, Mace T. An outlook for sustainable forest bioenergy production in the Lake States. Energ Policy 2009;37(12):5687-93.

[56] Aguilar FX, Saunders A. Policy instruments promoting wood-to-energy uses in the continental United States. J Forest 2010;108(3):132-40. 

(reworded/rephrased) for the stakeholder workshop in Phase III.

\begin{tabular}{|c|c|c|}
\hline Sustainability Principles & Criteria & Sub-criteria/Indicators \\
\hline \multirow[t]{24}{*}{ Economic } & \multirow{6}{*}{$\begin{array}{l}\text { Contribution to local } \\
\text { economy }\end{array}$} & Employment \\
\hline & & Use of local resources \\
\hline & & Value-addition to forest products \\
\hline & & $\begin{array}{l}\text { Infrastructure development (roadways, railways, hospitals, training } \\
\text { institutes) }\end{array}$ \\
\hline & & Benefit from external trade \\
\hline & & Youth population in the region \\
\hline & \multirow{3}{*}{ Energy security } & Net energy import dependency \\
\hline & & Consistent/Reliable supply of energy products \\
\hline & & Competitive cost of biofuel \\
\hline & \multirow[t]{7}{*}{ Economic viability } & Cost of production/operation \\
\hline & & Energy return over investment (EROI) \\
\hline & & $\begin{array}{l}\text { Energy from forest-based biomass compared to energy from fossil } \\
\text { fuels; British Thermal unit (BTU) per volume }\end{array}$ \\
\hline & & $\begin{array}{l}\text { Travel distance between production and distribution points; Within } \\
\ldots . \mathrm{km}\end{array}$ \\
\hline & & Return over investment; Net investment/ initial investment \\
\hline & & $\begin{array}{l}\text { Resource efficiency of the process; Fuel production per volume of } \\
\text { feedstock or hectare }\end{array}$ \\
\hline & & Scale of production: Local/Regional \\
\hline & \multirow{6}{*}{$\begin{array}{l}\text { Market acceptance \& } \\
\text { adaptability }\end{array}$} & Ability to use diverse feedstock \\
\hline & & Ability to produce diverse products/co-products \\
\hline & & Return rate; Payback time in years \\
\hline & & Cost of returning to previous land use \\
\hline & & Comparative gain over other investments \\
\hline & & $\begin{array}{l}\text { Technology, infrastructure, machineries and equipment; Production } \\
\text { of energy, use of energy }\end{array}$ \\
\hline & \multirow[t]{2}{*}{ Competition for resources } & $\begin{array}{l}\text { Availability of forest biomass; Price and availability of forest } \\
\text { products }\end{array}$ \\
\hline & & Availability of lands for other purposes; Land price; land availability \\
\hline \multirow[t]{12}{*}{ Environmental } & \multirow[t]{2}{*}{ Air quality } & $\begin{array}{l}\text { GHG emissions; } \mathrm{CO}_{2} \text { equivalent emissions, change in carbon } \\
\text { sequestration properties }\end{array}$ \\
\hline & & Particulate matter, $\mathrm{NOx}, \mathrm{SOx}, \mathrm{CO}$ \\
\hline & \multirow{4}{*}{$\begin{array}{l}\text { Ecosystem and wildlife } \\
\text { habitat }\end{array}$} & Biodiversity \\
\hline & & Controlled use of agrochemicals \\
\hline & & Avoid any disturbance to high conservation value areas \\
\hline & & Controlled use of forestland for bioenergy operations \\
\hline & Invasiveness & $\begin{array}{l}\text { Use of non-native species/genetically engineered species for } \\
\text { bioenergy production }\end{array}$ \\
\hline & Water quality and quantity & $\begin{array}{l}\text { Prevent water contamination (Herbicide concentrations in water, } \\
\text { pH, eutrophication) }\end{array}$ \\
\hline & \multirow[t]{2}{*}{ Land/Soil quality } & $\begin{array}{l}\text { Productivity/yield, soil organic compounds, soil nutrient, } \mathrm{pH} \text {, soil } \\
\text { compaction }\end{array}$ \\
\hline & & Land (soil) conservation/management \\
\hline & \multirow[t]{2}{*}{ Waste management } & Residue management and utilization \\
\hline & & Waste management; Waste volume; Management plan \\
\hline \multirow[t]{12}{*}{ Social } & \multirow[t]{4}{*}{ Cultural value } & Access to recreational activities in public lands \\
\hline & & Protection of local/tribal heritage and sites \\
\hline & & Access to forest products for local inhabitants \\
\hline & & Aesthetics, change in forest cover, general cover type of the region \\
\hline & \multirow[t]{3}{*}{ Ethical concern } & $\begin{array}{l}\text { Avoid any disturbance in the livelihood of the local residents, } \\
\text { Improved neighborhood: Noise, smell, traffic }\end{array}$ \\
\hline & & Protection of land rights and access for local residents \\
\hline & & Work conditions; Income (fair wage/benefits); Safety \\
\hline & \multirow[t]{2}{*}{ Food security } & Availability of agricultural land; change in agricultural land area \\
\hline & & Food and feed (for livestock) price \\
\hline & \multirow{3}{*}{$\begin{array}{l}\text { Transparency/ } \\
\text { Participation }\end{array}$} & Involve public and citizen advisory panel in decision-making \\
\hline & & Public availability of management plans \\
\hline & & $\begin{array}{l}\text { Involvement of local organization, institutions or companies in the } \\
\text { monitoring and control process }\end{array}$ \\
\hline
\end{tabular}




\begin{tabular}{|c|c|c|}
\hline \multirow[t]{13}{*}{ Governance } & \multirow{6}{*}{$\begin{array}{l}\text { Precautionary and support } \\
\text { mechanisms }\end{array}$} & Sustainable harvesting guidelines \\
\hline & & Inventory of accessible forest resources \\
\hline & & Compliance to best management practices \\
\hline & & Subscription to certification schemes \\
\hline & & Subsidies and tax incentives \\
\hline & & $\begin{array}{l}\text { Policies to protect the local industry from impact of fluctuating oil } \\
\text { prices and foreign competition }\end{array}$ \\
\hline & \multirow{3}{*}{$\begin{array}{l}\text { Compliance with laws and } \\
\text { regulations }\end{array}$} & Payment of legally prescribed fees, taxes, royalties \\
\hline & & Compliance with local standards, laws and regulations \\
\hline & & Compliance with national and international standards \\
\hline & \multirow[t]{4}{*}{ Regulatory policies } & Restrict use of agricultural land \\
\hline & & Restrict use of forest and high conservation value areas \\
\hline & & Traffic controls \\
\hline & & Pollution control mechanisms \\
\hline \multirow[t]{10}{*}{ Institutional capacity } & \multirow[t]{3}{*}{ Integration and colocation } & $\begin{array}{l}\text { Mechanism to integrate bioenergy projects into existing } \\
\text { developmental projects and programs (e.g. carbon projects, } \\
\text { community development) }\end{array}$ \\
\hline & & $\begin{array}{l}\text { Co-location of bioenergy production on or near existing facilities } \\
\text { such as paper and pulp industries }\end{array}$ \\
\hline & & Education and training facilities to produce skilled workforce \\
\hline & \multirow[t]{4}{*}{$\begin{array}{l}\text { Administration and } \\
\text { Management }\end{array}$} & $\begin{array}{l}\text { Research and development programs for new technologies and } \\
\text { processes }\end{array}$ \\
\hline & & Communication and reporting of management and operation plans \\
\hline & & $\begin{array}{l}\text { Regular monitoring and evaluation of operational and management } \\
\text { systems by a third party }\end{array}$ \\
\hline & & Legal documentation of clearly stated tenure and contracts \\
\hline & \multirow[t]{3}{*}{$\begin{array}{l}\text { Communication and } \\
\text { outreach }\end{array}$} & $\begin{array}{l}\text { Events and workshops for mutual learning and information sharing } \\
\text { among key stakeholders }\end{array}$ \\
\hline & & Communication of research outcomes and long-term impacts \\
\hline & & A unit to facilitate communication between different stakeholders \\
\hline
\end{tabular}

708

709 


\section{Session A}

713

1. Research updates: Potential list of sustainability criteria and indicators (C\&I) derived from focus group discussions and telephone interviews.

2. Hands-on overview on Pairwise comparison, ranking, and rating methods for decisionmaking.

\section{Session B}

I. Individual Assessment (pairwise comparison and rated for relevance and importance): Criteria level

\begin{tabular}{|l|}
\hline Broad sustainability concerns \\
\hline Economic benefits \\
\hline Environmental protection \\
\hline Socio-economic benefits \\
\hline Policy and regulations \\
\hline Institutional capacity and strength \\
\hline Social criteria \\
\hline Improved neighborhood \\
\hline Aesthetics \\
\hline Recreational values (hunting, hiking, snow mobiling etc) \\
\hline Cultural products (herbs, fruits, firewood etc) \\
\hline Food security \\
\hline Educational/capacity building \\
\hline Environmental criteria \\
\hline Ecosystem services \\
\hline Biodiversity \\
\hline Air Quality \\
\hline Water quality and quantity \\
\hline Soil quality \\
\hline Climate change \\
\hline Land productivity \\
\hline Economic criteria \\
\hline Employment \\
\hline Infrastructure development \\
\hline Energy security \\
\hline Benefit from external trade \\
\hline Resource efficiency \\
\hline
\end{tabular}


II. Individual Assessment (rated for relevance): Criteria level

\begin{tabular}{|c|c|}
\hline $\begin{array}{l}\text { Environmental } \\
\text { criteria }\end{array}$ & Potential indicators \\
\hline \multirow{8}{*}{ Ecosystem } & Native forest cover \\
\hline & Land fragmentation \\
\hline & Natural grasslands area \\
\hline & State of areas with high conservation value \\
\hline & No. of wetlands/Peatlands \\
\hline & Population and habitat changes of species of concern \\
\hline & Wildlife population \\
\hline & $\begin{array}{l}\text { Invasiveness of species being used or introduced as } \\
\text { feedstock }\end{array}$ \\
\hline \multirow{6}{*}{ Air Quality } & Tropospheric ozone \\
\hline & CO emissions \\
\hline & SO2 emissions \\
\hline & Particulate matter (PM2.5, PM10) \\
\hline & Nitrogen Oxides emission \\
\hline & Odor \\
\hline \multirow{7}{*}{$\begin{array}{l}\text { Water Quality \& } \\
\text { Quantity }\end{array}$} & Biological Oxygen Demand level (eutrophication) \\
\hline & Dissolved Oxygen (DO) \\
\hline & Total suspended solids \\
\hline & Nutrient level in water sources \\
\hline & Herbicide concentration \\
\hline & $\mathrm{pH}$ (Acidification) \\
\hline & Depth of water table \\
\hline \multirow{7}{*}{ Soil Quality } & $\mathrm{pH}$ \\
\hline & Bulk density of the soil (Soil moisture) \\
\hline & Total organic carbon \\
\hline & Nitrate and phosphate concentration \\
\hline & Total exchangeable cations (causes change in $\mathrm{pH}$ ) \\
\hline & Amount of soil washed away \\
\hline & Soil compaction \\
\hline Climate change & GHG emissions \\
\hline Economic criteria & Potential indicators \\
\hline \multirow{7}{*}{$\begin{array}{l}\text { Resource efficiency } \\
\& \text { use }\end{array}$} & Price of wood $(\$)$ \\
\hline & Availability of wood \\
\hline & Land price \\
\hline & Land availability \\
\hline & Stress on water resource \\
\hline & Availability of agricultural land \\
\hline & Use of local resources versus imports \\
\hline \multirow{9}{*}{ Local economy } & Employment rate (Number of full time equivalent jobs) \\
\hline & Displacement of existing jobs \\
\hline & $\begin{array}{l}\text { Job types (direct versus indirect, service type versus other } \\
\text { etc) }\end{array}$ \\
\hline & Youth population in the region \\
\hline & State revenue (Local economy) \\
\hline & Diverse local economy \\
\hline & Expansion of road networks \\
\hline & New industries \\
\hline & $\begin{array}{l}\text { Infrastructures for public services (hospital, educational } \\
\text { institutions) }\end{array}$ \\
\hline
\end{tabular}




\begin{tabular}{|c|c|}
\hline \multirow{3}{*}{ Energy security } & Fossil Energy Return On Investment (Fossil EROI) \\
\hline & Local distribution of energy \\
\hline & External input/total input \\
\hline \multirow{3}{*}{$\begin{array}{l}\text { Benefit from external } \\
\text { trade }\end{array}$} & Terms of trade (Price of exports/price of imports) \\
\hline & Trade volume (in terms of income) \\
\hline & Consumption of resources versus production \\
\hline Social criteria & Potential indicators \\
\hline \multirow{4}{*}{ Work conditions } & Gender-based discrimination at work \\
\hline & Safety of workers \\
\hline & Health condition of workers \\
\hline & Fair wage conditions \\
\hline \multirow{2}{*}{ Food security } & Change in local agricultural land area \\
\hline & Food and feed (livestock) price \\
\hline \multirow{2}{*}{$\begin{array}{l}\text { Education/Capacity } \\
\text { building of the } \\
\text { community }\end{array}$} & Skill transfer and training opportunities \\
\hline & $\begin{array}{l}\text { No. of educational resources, and presence of information } \\
\text { resources }\end{array}$ \\
\hline \multirow{5}{*}{$\begin{array}{l}\text { Improved } \\
\text { neighborhood }\end{array}$} & Traffic volumes \\
\hline & Access to roadways \\
\hline & Crime rate \\
\hline & Odor \\
\hline & Noise \\
\hline
\end{tabular}

723 


\section{Participation and acceptance}

Key stakeholders participation in decision-making

Professional consulting services for landowners

Presence of landowners cooperatives

Protect landowners rights

Ability to be integrated into current use of lands

Low cost of returning to previous land use

Long-term contracts with the buyers of feedstock

\section{Profitability and benefits}

Return over investment

Return over time

Financial incentives/government incentives

Maintain land productivity

Comparative gain over other investment

Carbon emission reduction

Resource conservation

Land management opportunity

Infrastructure development

\section{Logistics}

Location of the plantation

Transportation facilities

Machineries and equipment (harvesting, collection, hauling)

Infrastructure (storage, processing)

Water source

Expertise in feedstock production

\section{Management and Monitoring}

Avoid use of chemical herbicides and fertilizers

Avoid clear-cutting

Avoid using heavy equipment for harvesting and collection

Avoid plantations in agricultural land

Protect ethical and cultural concerns of the local inhabitants

Residue management and utilization

Third party audit or assessment program (e.g., certification) 

and importance)

\begin{tabular}{|l|}
\hline Acceptability \\
\hline Adaptability to changing market \\
\hline Distance between plant and the market \\
\hline Ability to use diverse feedstock \\
\hline Ability to produce diverse products/co-products \\
\hline Competitive price \\
\hline Use of local resource \\
\hline Cost of setting up a supply chain \\
\hline Profitability and benefits \\
\hline Return over investment \\
\hline Return over time \\
\hline Value addition to the wood products \\
\hline Upfront cost requirement \\
\hline Scale of production/operation (local versus regional) \\
\hline Cost of production /operation \\
\hline Logistics \\
\hline Location of the plant \\
\hline Expertise (training facilities) \\
\hline Energy balance \\
\hline Consistent supply of feedstock/products \\
\hline Technology for efficient production \\
\hline Transportation for distribution \\
\hline Management and Monitoring \\
\hline Pollution control mechanisms \\
\hline Residue management and utilization plan \\
\hline Waste management plans \\
\hline Continuous research and pilot projects \\
\hline Transparency about management and operation plans \\
\hline Collaboration with existing forest-based industries \\
\hline $\begin{array}{l}\text { Local third party institutions' involvement in audit or assessment } \\
\text { program }\end{array}$ \\
\hline Local stakeholders' participation in decision-making \\
\hline
\end{tabular}



and importance)

\section{Regulatory policies}

Pay all applicable and legally prescribed fees, royalties, taxes should be paid

Compliance with state standards and regulations

Compliance with national and international standards and regulations

Restrict use of agricultural land

Restrict use of forests, wetlands and water courses

Restrict use of high conservation value areas

Protection of unique and significant tribal sites

Transparency

Involve citizen advisory panel in decision making

Public availability of management plan

A unit to facilitate communication between different stakeholders

Involvement of local organization/institutions/companies in the

management/control processes

Communication of research outcomes and long-term impacts

\section{Precautionary policies and support mechanisms}

Management prescription for sustainable harvesting

Compliance to best management practices

Subsidies/tax incentives

Subscription to certification schemes

Policies to protect the local industry from impact of falling oil prices/foreign competitions

Integration of bioenergy projects into existing developmental projects \& programs

\section{Management and Monitoring}

Reporting of management and operational activities.

Events and workshops for mutual learning/information sharing

Regular revision of management/operation decisions

Legal documentation of clearly stated tenure and use rights

Colocation of biorefineries on or near existing sites such as paper and pulp mills

Comprehensive R\&D programs for new technologies/processes 
Session D

744 Mixed group assessment (rated and ranked for relevance and importance)

Policy and institutional framework for wood-based bioenergy industry

Subsidies/tax incentives

Public participation in decision-making

Compliance with sustainable harvesting practices

Compliance with state and national regulations

Communication and reporting of management and operational decisions and plans

Continuous research

Regular monitoring

Maintain transparency in management/operation decisions

Collaborative learning, education, public awareness

Consumers' concerns regarding bioenergy products

Competitive cost

Compatibility with existing vehicle/technology

Convenience

Reliability (consistent supply of product)

Environment friendly

Efficiency

Renewable energy alternative

745 